\title{
Short communication: Differences in local perceptions of Osteochilus spilurus (Cyprinidae: Labeoninae) from several islands in Indonesia
}

\author{
ARDIANSYAH KURNIAWAN ${ }^{1,2, \bullet}$, DASA Y. PRAMONO ${ }^{3}$, ARTIN INDRAYATI $^{4}$, HERMANTO $^{5}$, \\ IRA TRISWIYANA ${ }^{5}$ \\ ${ }^{1}$ Doctoral Program in Fisheries Science and Marine, Faculty of Fisheries and Marine Science, Universitas Brawijaya. Jl. Veteran, Malang 65145, \\ East Java, Indonesia \\ ${ }^{2}$ Departement of Aquaculture, Faculty of Fisheries, Agriculture and Biology, Universitas Bangka Belitung, Balunijuk, Merawang, Bangka, 33172, \\ Kepulauan Bangka Belitung, Indonesia. Tel./fax.: +62-717-422145, "email: ardian_turen@yahoo.co.id \\ ${ }^{3}$ Fisheries and Marine Departement of North Lampung District, Jl. Alamsyah RPN 327, North Lampung, Lampung, Indonesia \\ ${ }^{4}$ Sekolah Usaha Perikanan Menengah Kota Agung. Jl. Pantai Harapan, Tanggamus, Lampung, Indonesia \\ ${ }^{5}$ Research Institute for General Waters Fisheries and Fisheries Extension. J1. Gubernur H.A Bastari 8, Palembang, South Sumatra, Indonesia
}

Manuscript received: 4 October 2020. Revision accepted: 26 October 2020.

\begin{abstract}
Kurniawan A, Pramono DY, Indrayati A, Hermanto, Triswiyana I. 2020. Short communication: Differences in local perceptions of Osteochilus spilurus (Cyprinidae: Labeoninae) from several islands in Indonesia. Asian J Ethnobiol 3: 79-84. Osteochilus spilurus is native freshwater fish on the islands of Sundaland, Indonesia. No study has reported this fish utilization other than in the Belitung Islands, so another local perception of the Indonesian island needs to be investigated. Local recreational fishing in Palangkaraya, Pontianak, and Pekanbaru and fishers in Palangkaraya, Eastern and western of Belitung, Southern and Central Bangka, and North Lampung were the sources of local knowledge. We obtained data using a Facebook app survey to see local recreational fishers' awareness, interviews with one fisherman in each region, and a literature review for Belitung public perception. There is a different awareness of people from East Belitung to the other areas. In East Belitung, knowledge of $O$. spilurus links to the local culture. Fishers have the most relevant fishing gear expertise for the catch of $O$. spilurus, based on environmental factors and fish behavior. Large-scale fishing, consumption, and trade only take place in East Belitung. It is impacted by non-environmentally sustainable mesh size nets that threaten their natural survival.
\end{abstract}

Keywords: Local knowledge, native fish, Osteochilus spilurus, Sundaland

\section{INTRODUCTION}

Indonesia is rich in ichthyofauna species in inland waters as a mega biodiversity country. The freshwater fish species were identified as 1,243 species, with $16 \%$ Cyprinidae (Fishbase 2020). As a part of Southeast Asia, the diversity of Cyprinidae in Indonesia is due to the Pleistocene Period (Dott and Prothero 1994). This period, which is often referred to as the ice age, has resulted in changes in river flow, the emergence of millions of lakes, sea-level changes, and the appearance of pluvial lakes. Sea level declined to $150 \mathrm{~m}$ in the last glaciation process connected to the lands now separated by oceans (Gradstein et al., 2004). The rise of seawater forms Indonesia's territory in the archipelago formation and has become one of the world's most ethnically diverse nations. More than 600 ethnic groups with over 400 languages in Indonesia (Nababan 1985). These differences have led to various naming fish species in the local language.

Osteochilus spilurus is a member of the Cyprinidae, widely distributed in Southeast Asia. This fish was identified in the Malay Peninsula and Sabah in Malaysia, South Sumatra, Lampung, West Kalimantan, Central Kalimantan, and South Kalimantan in Indonesia (GBIF 2019). This species is not yet widespread in Indonesia like other Osteochilus such as $O$. vittatus, $O$. hasselti, and $O$. waandersii developed as a fishery cultivation commodity. This fish does not even have an Indonesian name, so its naming depending on the local name dan allows the perception of different fish. That has happened in the Eastern of Belitung Island, where the people think this fish is endemic because it is not found in other areas (Saad 2012). This perception can be caused by economic value and large consumption in East Belitung (Kurniawan et al. 2016).

Many publications only position this fish as one of the fish listed in the freshwater river. Understanding the distribution on average comes from reports on river biodiversity, so that community response to this species has not been recorded. It raises the possibility of the conventional use of this fish in other regions that have never been reported before. Information on fish utilization is essential for its development and conservation. For this reason, a study of community perceptions on $O$. spilurus was carried out in several islands that are part of its distribution area in Indonesia. It is hoped that new material may be available that will supplement the socio-ethno knowledge of $O$. spilurus. 


\section{MATERIALS AND METHODS}

\section{Observation location}

The observations were conducted on local recreational fishing and fishers. Information from local recreational fishing was used online discussion in three locations, i.e., Palangkaraya and Pontianak regions of Borneo Island and Pekanbaru areas of Sumatra Island. Six places in the western part of Indonesia were interviewed by $O$. spilurus fisherman, namely Palangkaraya on Borneo Island, Eastern and Western of Belitung Islands, South Bangka and Bangka on Bangka Island, and North Lampung on Sumatra Island. We observed eight regions in four Sundaland islands (Figure 1). The survey was completed between July and September 2020.

\section{Methods}

This research utilizes a stationary camera, mobile, Facebook application, and questionnaire. Survey methodology and literature review were used to obtain data. The survey was undertaken to collect locals information and to question fishers about the opinion of
O. spilurus. The survey was performed using the Facebook app to see local recreational fishers' awareness carried out on $O$. spilurus. For locals, questions about recreational fishing are limited to their familiarization with the fish's photo (Figure 2). Informants are group members who respond to questions. Responses are presented in graphical form to show the local awareness towards $O$. spilurus.

We used secondary public perception data from the Gantung sub-districts, East Belitung (Kurniawan and Triswiyana 2019), and the Membalong sub-districts in the West Belitung (Kurniawan et al. 2020) for Belitung residents views. Both data are compared on introduction, consumption, how to get the fish, and to catch season knowledge. The comparison results are shown in graphical form.

Meanwhile, interviews with one fisherman in each region were undertaken to learn more about fish use and catch knowledge. Utilization, trading, economic value, and other fishing-related things become references for discussion with fishers. Observational data have been descriptively represented and illustrated in tables and images.

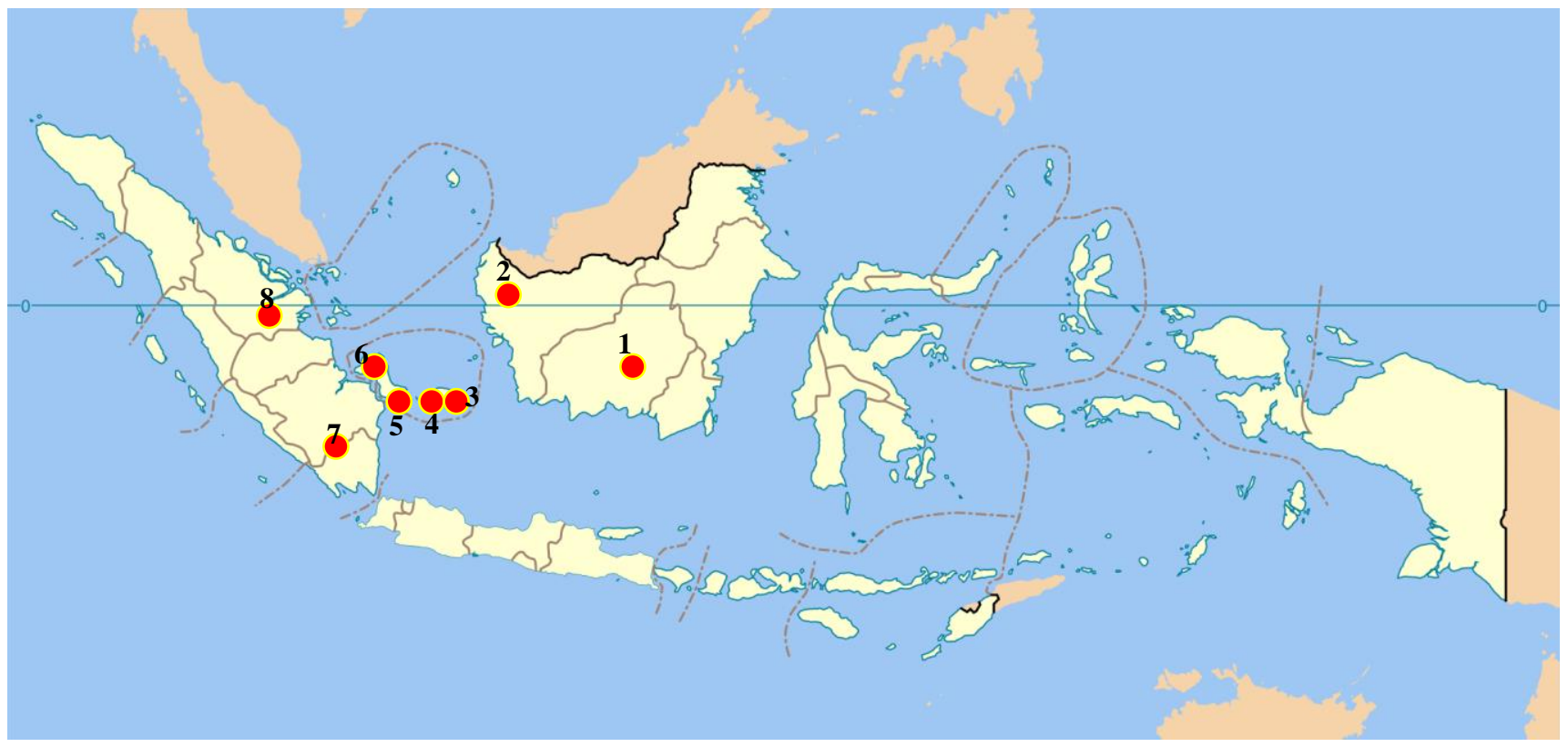

Figure 1. Maps of observation locations in this study. 1. Palangkaraya, 2. Pontianak, 3. East Belitung, 4. Western of Belitung, 5. South Bangka, 6. Central Bangka, 7. North Lampung, 8. Pekanbaru
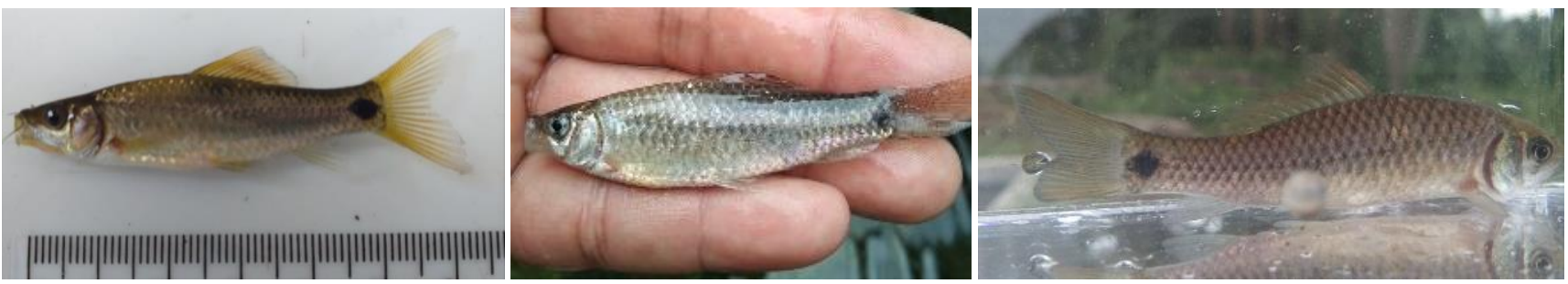

Figure 2. Osteochilus spilurus photographs for awareness survey of local recreational fishers 


\section{RESULTS AND DISCUSSION}

\section{Residents perception}

There is a gap in people's understanding of O. spilurus, where more people talk about it on Belitung Island instead of Palangkaraya, Pontianak, and Pekanbaru. Belitung's people name this fish as Cempedik fish stands for "macem empedu di aik," meaning water-like bile. It is called Kepait on Bangka Island, which means bitter. Residents of Palangkaraya call Seluang Licin. Some citizens know it in Pontianak as Seluang Batu, and in Pekanbaru as Siburuk or Sibuok. Pulungan (2009) says that Siburuk fish is a local name of $O$. spilurus in Riau. The definition of Siburuk refers to the state of the fish that quickly rots and splits its intestine. The local name of $O$. spilurus in another region was verified using the fishermen's interview information. In areas beyond Belitung Island, $O$. spilurus is limited, with most respondents not understanding or mentioning various fish (Figure 3).

The graph shows that although local respondents from Palangkaraya, Pontianak, and Pekanbaru are recreational anglers, often associated with rivers and fish, they are less familiar with $O$. spilurus than the general public Belitung Island. This fish is also the same as other small fish outside Belitung Island. Wader (Barbodes binotatus), Bantak (Osteochilus wandersii), Puyau (Osteochilus hasselti), Lelan (Diplocheilichthys pleurotaenia), and Seluang (Rasbora $\mathrm{sp}$ ) is considered to be the same as O. spilurus because they have the same several characters, especially in size. These fish are often caught together because they swim in the same schooling (Fakhrurrozi et al., 2016). This reaction explains that $O$. spilurus has little relationship with humans in regions outside of Belitung Island. Meanwhile, the high identification in Belitung is due to the increased strength of O. spilurus and humans' interaction.

There are two reasons for the familiarization of the Belitung community with $O$. spilurus. The first is the practice of eating it. People want to consume this fish (Kurniawan and Triswiyana 2019). Fish are processed with special handling to remove the bitter taste (Kurniawan et al. 2019). They use a stick of coconut leaf to empty the stomach contents from the anus hole of the fish. The use of a knife is not ideal because of the small size of the fish. The second reason is that this fish is considered close to the culture of the Belitung people. This local wisdom is demonstrated by the presence of a traditional song with the title "Ke Pice" (Fakhrurrozi 2015) depicting Cempedik fishing in the Pice dam and its flavor description and a modern Belitung batik with a Cempedik fish motif (Detiktravel 2015). In other regions, symptoms related to such a culture are not seen.

\section{Belitung residents perception}

The residents' reaction to $O$. spilurus in East Belitung and West Belitung shows a distinct perception based on analyzed data from the Kurniawan and Triswiyana (2019) and Kurniawan et al. (2020) surveys. This fish's consumption and trade are higher in East Belitung, while the people of West Belitung prefer individual catches. After his capture, there are also differences between the two regions, where individuals in East Belitung feel more comfortable being captured in the rainy season. By contrast, it is the dry season that the inhabitants of West Belitung say (Figure 4).

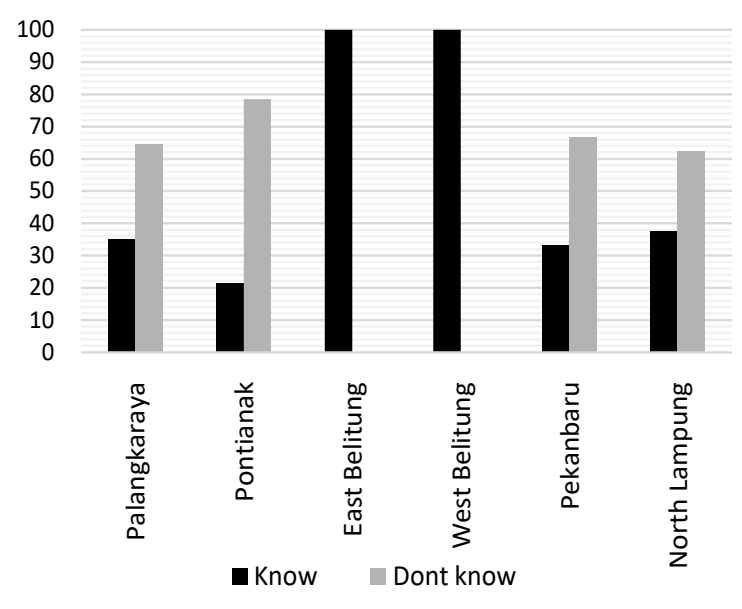

Figure 3. Percentage of respondents in multiple regions who know about Osteochilus spilurus

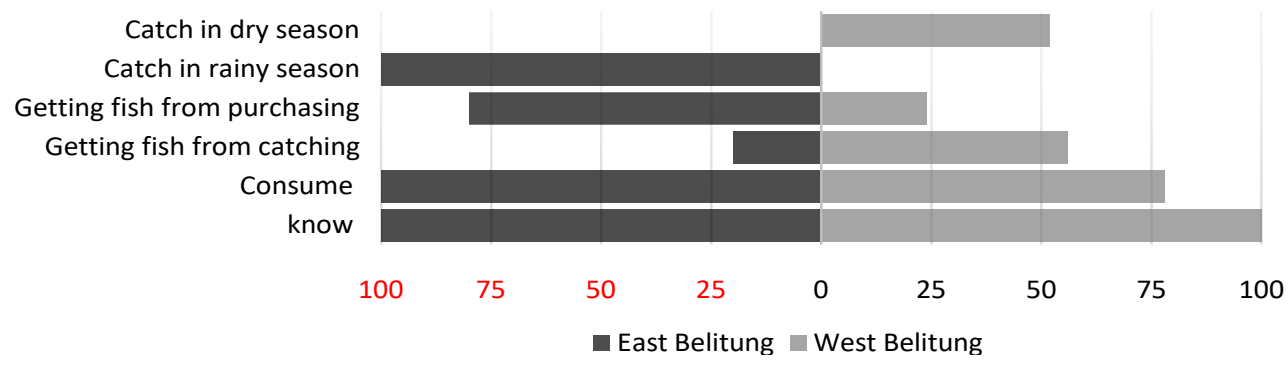

Figure 4. Belitung resident's response of Osteochilus spilurus 


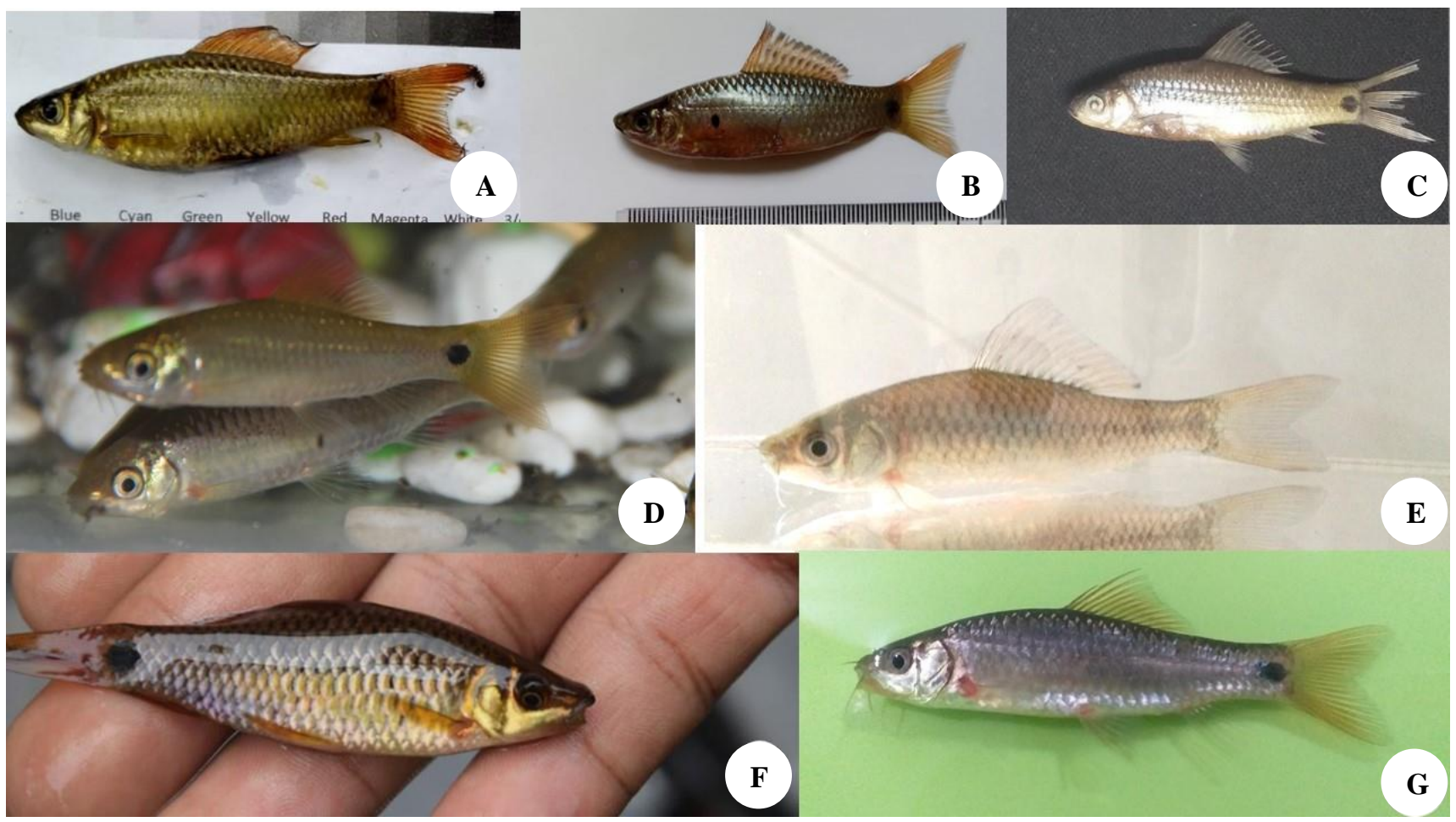

Figure 5. Photograph of Osteochilus spilurus from fishermen from six regions. A. South of Bangka, B. Western of belitung, C. Palangkaraya, Borneo, D and F. East Belitung, E. North Lampung, Sumatra, G. Central Bangka

The fishing season variation is due to a community guide's local awareness of fishing activities in the river setting. The significant fish sources in Belitung are the Lenggang and Kembiri rivers, large rivers with different conditions. In East Belitung, the Lenggang River has a dam that has the capacity in the rainy season to trigger currents and does not dry out in the dry season. Meanwhile, the Kembiri River dries out in the dry season, giving rise to water pools in the deeper portion of the river. Through their respective ethnic technology, fish catchers adapt to the habits of $O$. spilurus. Fisherman East Belitung uses fish traps to capture fish on the river bank against the current (Fakhrurrozi et al., 2016). People from Western Belitung wait for low deep water to make it possible for successful fishing gear to catch fish. Fishing gear ethnic technology is a breakthrough in fishing productivity for local communities (Nurdin and Ng 2013). Fishers' adaptation to the environment is their effort to get the best catch (Musinguzi et al., 2016).

\section{Fisherman knowledge}

The Fishermen recognize O.spilurus even though they only know its local name. The fisherman showed a similar fish to O.spilurus, as in Figure 5. These fish have the same morphological character of $O$. spilurus described by Weber and de Beaufort (1916), i.e., tight body, snout cone, dorsal height gradually increasing in size before dorsal fin, lateral line with 28-30 scales, dorsal fin with 12-13 rays, the emarginate shape of the caudal fin, long maxillary barbels, and a large black blotch on the caudal peduncle.

Table 1. Resume of the interview with fishers in six regions in Indonesia

\begin{tabular}{lllllll}
\hline Region & Local name & Utilization & Trade & Economical & Fishing gear & Capture season \\
\hline & & & & & & \\
Palangkaraya & Seluang licin & Consume & Yes & Yes & Lift net & Dry season \\
East Belitung & Cempedik & Consume & Yes & Yes & Fish trap, nets & Rainy season \\
West Belitung & Cempedik & Consume & No & No & Nets, fish trap & Dry season \\
South Bangka & Kepaet & No & No & No & Fish trap & Dry season \\
Bangka & Kepaet & Consume & No & No & Nets, fish trap & Dry season \\
North Lampung & Seluang sungai & Fish feed & No & No & Lift net & All season \\
& & & & & &
\end{tabular}




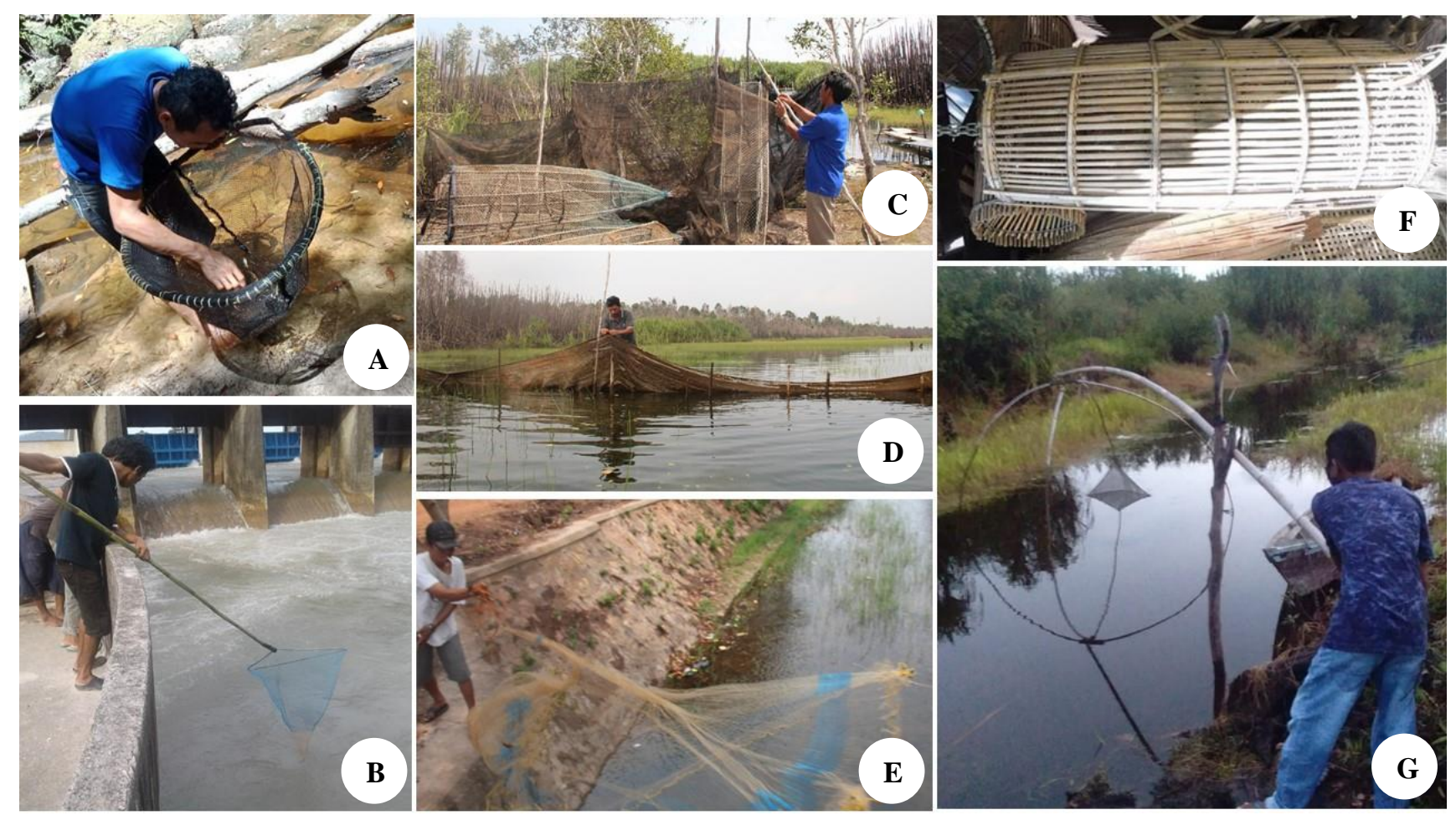

Figure 6. Fishing gear that using for Osteochilus spilurus catching. A. Scoop nets in Air Tering River, West Belitung, B. Scoop nets in Pice Dam, East Belitung, C-D. Fish trap called "Sero" in Lenggang River, East Belitung, E. Jala, F. Bamboo fish trap, G. Lift nets in Palangkaraya

Its use, which has economic importance, can only be seen in the region of East Belitung, while other areas in Belitung island are not traded (Tabel 1). Trade is only in East Belitung and Palangkaraya, but there is an imbalance from the price point of view, even though the sale and purchase system is in the same device, namely the nonstandardized cup. In East Belitung, this fish's price is Rp. 10,000 per cup of an average one kilogram consisting of five cups, while the price in Palangkaraya is Rp. 3000 to Rp. 5000 in a bowl. The informant of Lampung fishers usually uses O.spilurus to feed his predatory fish cultivation. However, when the catch of small fish is abundant, O.spilurus trades in the mix with other fish with a small bowls trading unit.

The fishing gear used by fishermen varies according to the environmental conditions of the river as well. The Palangkaraya and North Lampung capture have the same tool, namely the lift net, while others use the fish traps and nets to get these fish. Passive fishing gear is more often used for capturing this fish (Figure 6).

In West Belitung, fish in small rivers are collected using scoop nets constructed from a small mesh-size net (Figure 6a). When the water level is lowest, or the fish are trapped in river pools during the dry season, this fish is more comfortable to capture. Tangguk (Figure 6b), a long stick scoop net, was also found in the Pice dam portion of the Lenggang River, East Belitung. The fish that fell from the dam stream attempt to return by jumping on the riverbank. This moment makes it possible for fishers to capture it (Kurniawan et al., 2016).

Bubu, made of bamboo or rattan, are typically the fish traps used by fishermen in each area (Figure 6f). This tool is used in limited numbers to capture fish, but its compact size allows it to be mounted in several places. Bubu is popularly used in rivers, swamps, and lakes as a tool to trap fish (Koeshendrajana \& Cacho 2001). When the placement process does not harm the environment, Bubu is not a destructive fishing gear (Pet-Soede \& Erdmann 1998).

Many catches are expected by the high demand for fish in East Belitung, so fishers make a large fish trap made of set nets called Sero (6c). Set nets are put in a schooling fish environment on the riverbank with the mouth opposite the river flow direction. They understand the behavior of $O$. spilurus swimming in groups against the current on the riverbank when the river is inflow (6d). Set net is generally used as fishing gear in marine waters (Madduppa et al. 2014) and used in Nujiang River, China (Pan et al. 2017). It is considered environmentally friendly fishing gear (Bubun et al. 2015; Salim et al. 2019). Nevertheless, the set nets forms applied in the Lenggang River also resemble aerial traps, categorized as fishing tools that are disturbing and damaging to the minister of Marine Affairs and Fisheries of Indonesia No. 712016 (KKP, 2016). The use of $5 \mathrm{~mm}$ mesh size nets as material fishing gear endangers fish's natural sustainability because of their low selectivity (Muthmainnah et al., 2014). 
The use of nets is carried out in throwing nets and lift nets. In the Lebak river, Bangka Regency, throwing nets is usually used to capture fish with the primary target other than O. spilurus. The lift net in North Lampung is equipped with lights as an attractor at night. Early in the morning, the fisher raised the lift nets only to pick the fish once one night. Meanwhile, in Palangkaraya, lift nets are carried out during the day when fish are trapped in the fishing gear. Lift nets are fishing gear commonly used in rivers (Sugeng et al., 2019). If the attractor in the form of lights is neglected, catching fish using lift nets during the day is more effective than at night (Kirana et al., 2015). The selection of nets with a mesh size that allows the fish to grow up is necessary for sustainability in their natural habitat (Takar \& Gurjar 2020).

This study finds that the individual's knowledge about O. spilurus in Belitung Island compared to other regions varies. In East Belitung, in particular, the ability has a connection with the local culture. All fishermen know of the most appropriate fishing gear for O. spilurus depending on environmental conditions and fish behavior. Large-scale fishing, eating, and trading takes place in East Belitung. It impacts the use of mesh scale nets that are nonenvironmentally friendly and endanger their natural existence.

\section{ACKNOWLEDGEMENTS}

We sincerely thank LPDP (Indonesia Endowment Fund for Education) for providing me with financial support during the first author doctoral study and research in Universitas Brawijaya, Indonesia Suhery, Nicko, Andres, and Fitri for field assistance and members of the fishing mania Facebook group in Pekanbaru, Palangkaraya, and Pontianak.

\section{REFERENCES}

Bubun R, Fajriah F, Marlisa N. 2015. Composition of catches and hospitality level of Sero fishing gear in the village of Tapulaga, Southeast Sulawesi. Jurnal Airaha 4 (2): 48-56. [Indonesian]

Detiktravel. 2015. Not only Java, Belitung also has batik!. https://travel.detik.com/. [Indonesian]

Dott RH, Prothero DR. 1994. Evolution of the Earth, McGraw-Hill. Inc. New York.

Fakhrurrozi Y, Kurniawan A, Kurniawan A. 2016. Development of Cempedik fish potential in East Belitung: A biological and ethnobiological approach. Scripta Biologica 3 (4): 1-15. DOI: 10.20884/1.sb.2016.3.4.49. [Indonesian]

Fakhrurrozi, Yulian. 2015. Fish and fish-related cultural products in the work of Belitung traditional songs. Proceedings of the 8th National Fish Seminar 2014, Bogor. DOI: 10.20884/1.sb.2016.3.4.49. [Indonesian]

Fishbase. 2020. List of Freshwater Fishes reported from Indonesia https://www.fishbase.se/country/CountryChecklist.php?resultPage $=17$ $\&$ what $=$ list $\&$ trpp $=50 \& c \_$code $=360 \&$ sortby $=$ alpha $2 \&$ ext_CL $=$ on \&ext _pic $=$ on\&vhabitat $=$ fresh $[10 / 07 / 2020]$

GBIF. 2019. Osteochilus spilurus (Bleeker, 1851). GBIF Backbone Taxonomy. DOI: 10.15468/39o accessed via GBIF.org [2020-09-15].

Gradstein F, Ogg J, Smith A. 2004. A Geologic Time Scale 2004 Cambridge University Press, New York. DOI: 10.1017/CBO9780511536045.
Kirana EN, Boesono H, Fitri ADP. 2015. Analysis of catch results on Anco fishing equipment (lift net) based on the difference in operating time day and night in the Kedungombo Boyolali Reservoir. J Fish Resour Util Manag Technol 4 (4): 125-134 [Indonesian]

KKP. 2016. Regulation of the minister of marine affairs and fisheries of the Republic of Indonesia Number 71/PERMEN-KP/2016 concerning fishing routes and placement of fishing gear in the fisheries management area of the Republic of Indonesia. [Indonesian]

Koeshendrajana S, Cacho OJ. 2001. Management options for the inland fisheries resource in South Sumatra, Indonesia: I bioeconomic model. Working Paper Series in Agricultural and Resource Economics University of New England, Armidale, Australia.

Kurniawan A, Fakhrurrozi Y, Kurniawan, A. 2016. Ethnozoological study of cempedik fish in Lenggang River, Gantung, East Belitung Regency. Akuatik 10 (1): 6-12. [Indonesian]

Kurniawan A, Kurniawan A, Fakhrurrozi Y, Widyanthi F, Setiawan J, Kartika K, Arezki T. 2020. Local knowledge of Cempedik Fish (Osteochilus spilurus) in Membalong District, Belitung. Journal of Aquatropica Asia 5 (1): 16-20. [Indonesian]. DOI: 10.33019/aquatropica.v5i1.1823.

Kurniawan A, Kurniawan A, Fakhrurrozi Y. 2019. Potential development of Cempedik fish (Osteochilus spilurus) in East Belitung: a study of consumption, handling, and nutrition. Acta Aquatica Aquat Sci J 6 (1): 32-36 [Indonesian]. DOI: 10.29103/aa.v6i1.1262.

Kurniawan A, Triswiyana I. 2019. Perception of the economic utilization and sustainability of Cempedik fish (Osteochilus Spilurus) in East Belitung Regency. ECSOFiM (Economic and Social of Fisheries and Marine) 7 (01): 109-119. [Indonesian]

Madduppa HH, von Juterzenka K, Syakir M, Kochzius, M. 2014. Socioeconomy of marine ornamental fishery and its impact on the population structure of the clown anemonefish Amphiprion ocellaris and its host anemones in Spermonde Archipelago, Indonesia. Ocean Coast Manag 100: 41-50. DOI: 10.1016/j.ocecoaman.2014.07.013.

Musinguzi L, Efitre J, Odongkara K, Ogutu-Ohwayo R, Muyodi F, Natugonza V, Naigaga S. 2016. Fishers' perceptions of climate change, impacts on their livelihoods and adaptation strategies in environmental change hotspots: A case of Lake Wamala, Uganda. Environ Develop Sustain 18 (4): 1255-1273. DOI: 10.1007/s10668015-9690-6.

Muthmainnah D, Makri S, Atminarso D, Sawestri S, Makmur S. 2014. Selectivity and effectiveness of different gillnet mesh sizes used in Ranau Lake of Sumatra. J Biodivers Environ Sci 5 (5): 82-89.

Nababan PWJ. 1985. Bilingualism in Indonesia: Ethnic language maintenance and the spread of the national language. Asian J Soc Sci 13 (1): 1-18. DOI: 10.1163/080382485X00020.

Nurdin BV, Ng KSF. 2013. Local knowledge of Lampung people in Tulang Bawang: an ethnoecological and ethnotechnological study for utilization and conservation of rivers. Procedia-Soc Behav Sci 91: 113-119. DOI: 10.1016/j.sbspro.2013.08.408

Pan L, Cheng XW, Xu J, Yang T, Li PP, Wang ZX, Shao DG. 2017. Length-weight relationships of four fish species from the Nujiang River, China. J Appl Ichthyol 33 (6): 1299-1300. DOI: 10.1111/jai.13476.

Pet-Soede L, Erdmann M. 1998. An overview and comparison of destructive fishing practices in Indonesia. SPC Live Reef Fish Inform Bull 4: 28-36.

Pulungan CP. 2009. Fish fauna from the Tenayan River, a tributary of the Siak River, and the surrounding swamps, Riau. Berkala Perikanan Terubuk 37 (2): 78-90. [Indonesian]

Saad S. 2012. I found "A Ling," starting from the Tin Museum to the Word

Museum. https://www.kompasiana.com/santorry/55198ff9a333114019b6594e. [10/24/2020] [Indonesian]

Salim G, Firdaus M, Alvian MF, Indarjo A, Soejarwo PA, Prakoso LY. 2019. Socio-economic analysis and environmental friendliness of sero fishing gear (set net) in the waters of Bangkudulis Island, Tana Tidung Regency, North Kalimantan. Buletin Ilmiah Marina Sosial Ekonomi Kelautan dan Perikanan 5 (2): 85-94. [Indonesian]. DOI: 10.15578/marina.v5i2.8112.

Sugeng S, Khristyson SF, Yusim AK. 2019. Floating equipment design module for fish catching activities with Anco catching equipment. Jurnal Pengabdian Vokasi 1 (1): 43-47. [Indonesian]

Takar S, Gurjar UR. 2020. Minimum legal size: A tool for sustainable fisheries management. Biotica Res Today 2 (7): 658-660.

Weber MWC, de Beaufort LF. 1916. The Fishes of the Indo-Australian Archipelago. E.J. Brill Limited, Nederland. 